\title{
GC-MS Analysis and Antimicrobial Activities of Ethanol Alkaloid Leaf Extracts of Delonix elata.L
}

\author{
D.Muthuselvam*, Kathick \\ *Assistant Professor, Department of Botany, Bishop Heber College, Affiliated to Bharathidasan University, Puthur, Tiruchirappalli, Tamil \\ Nadu, India. \\ *Corresponding author's E-mail: msbhcbot@gmail.com
}

Received: 18-03-2021; Revised: 22-05-2021; Accepted: 30-05-2021; Published on: 15-06-2021. \begin{abstract}
Delonix elata L., belongs to family Fabaceae used by the traditional various medicinal practices to cure jaundice, skin disease, heart disease, cancer cell formation, physiological abnormalities, heptoprotective, bronchial and rheumatic problems. The present study was screen the antimicrobial and phytochemical activity of alkaloid leaf extracts. This extracts was assessed on multidrug resistant clinical isolated from both gram positive, gram negative and antifungal strains including Bacillus subtilis, Staphylococcus aureus, Escherchia coli, Pseudomonas aeruginosa, Candida albicans and Aspergillus niger. The zone of inhibition was determined by Agar well diffusion method with various concentration. GC- MS analysis was performed to identify major bioactive compounds present in the extracts. The GC - MS studies shown the present of 25 compound were identified in the leaf extract composition. The antimicrobial analysis revealed that $C$. albicans showed a highest zone of inhibition $25 \mathrm{~mm}$ at $100 \mathrm{mg} / \mathrm{ml}$ of extracts. Present finding suggest that $D$. elata as plant pharmaceutical and pharmacological importance.
\end{abstract}

Keywords: Alkaloid leaf extracts, Antimicrobial, GC- MS analysis, pharmacological importance.

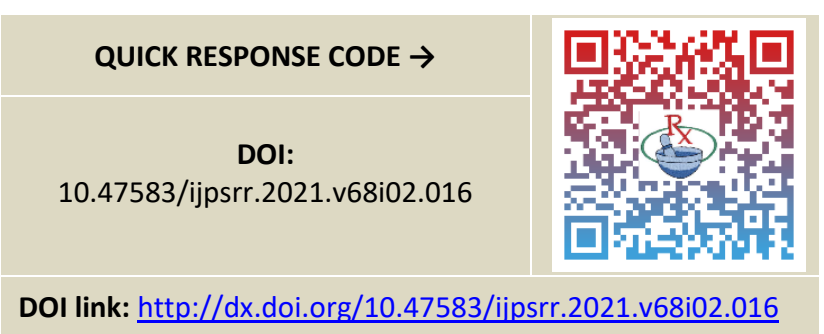

\section{INTRODUCTION}

A ntibiotics have saved millions of lives and contributed to significant increases in life expectancy over the last century. However, the emergence of multi-drug resistant pathogens is threatening the clinical efficacy of many existing antibiotics. ${ }^{1,13}$ The recent emergence of strains with decreased susceptibility, as well as the unfavorable side effects of certain antibiotics ${ }^{2}$. Infectious diseases caused by resistant microorganisms are associated with longer hospital stays, higher costs, and an increased risk of morbidity and mortality. Resistance is a particularly difficult issue for people with compromised immune systems, such as those suffering from AIDS or cancer patients. The Promiscuous antibiotic use accounts for a significant portion of the community burden of antibiotic use and significantly contributes to the rising prevalence of resistance among major human pathogens. The development of extended-spectrum antibiotics that target Gram-negative bacteria has resulted in infections that can be extremely difficult to treat, resulting in significantly increased illnesses and deaths. The resistance problem necessitates a renewed effort to screen various medicinal plants for potential antimicrobial traits caused by compounds synthesised in the plant's secondary metabolism. Alkaloids, flavonoids, tannins, phenolic compounds, steroids, resins, fatty acids, and gums are the most important bioactive compounds found in plants. Another motivator for scientists to look for new antimicrobial substances from various sources, including medicinal plants, has been the rapid extinction of plant species. Medicinal plants are used by 80 percent of the world's population, and India has a long history of using herbal medicine to treat a variety of infectious diseases, inflammations, injuries, and illnesses. Many plant materials used in traditional medicine have been shown to be more effective and less expensive than modern medicine ${ }^{4,15}$ against certain ailments while also mitigating many of the side effects commonly associated with synthetic antimicrobials ${ }^{5-7}$. The majority of the research is aimed at determining the activity of plant extracts against a variety of test bacteria, including both pathogenic and nonpathogenic strains.

Delonix elata is a belonging to the family Fabaceae and deciduous tree about 2.5-15 m tall, with a spreading, rather rounded crown, crooked poor stem form and drooping branches. Bark smooth, shining; sometimes flaking. Leaves 3-6 or more, bipinnate; pinnae usually 4-6 pairs; leaflets 10-14 pairs, oblong or oblanceolate-oblong, $0.6-1.2 \mathrm{~cm}$ long. Leaflets $1.25-4 \mathrm{~mm}$ wide, smaller than those of D. regia. Flowers in terminal corymbs; stalks pubescent, lowest flowers stalks longest. Flowers open one at a time. Sepals $1.8 \mathrm{~cm}$ long, with a broadly ovate or rotundate-cuneate lamina narrowing into a distinct claw. Petals rounded in outline and crisped on margins 1.6-3.8 $\mathrm{cm}$ long, 1.8-4.2 cm wide; upper one smaller than rest, pale yellow; the remainder white; later all turning apricot. Staminal filaments pale brown or reddish, hairy at the 
base, 5-10 cm long; pedicels up to $3.75 \mathrm{~cm}$. Ovary pubescent or tomentose all over. Pods red-brown or purple-brown, up to $20 \mathrm{~cm}$ long and smooth, compressed elliptic-oblong. Delonix is widely used by the traditional medical practitioners of Karnataka, India, to cure jaundice, diabetics, bronchial, Wound healing and rheumatic problems. Bark extracts have shown potential antioxidant and hepatoprotective activity.

Despite an abundance of literature on the antimicrobial properties of plant extracts, none of the plant-derived chemicals have been successfully used as antibiotics in clinical trials. A significant portion of plant chemical diversity is thought to protect plants from microbial pathogens. As a result, the purpose of this study was to investigate the antimicrobial potentiality of various fungal and bacterial strains and Phytochemical investigation of $D$. elata.

\section{MATERIALS AND METHODS}

\section{Collection of Plant Materials}

Delonix elata. L leaves were collected from Somarasam pettai, Tiruchriappalli district of Tamil Nadu, India. Department of Botany, Bishop Heber College, Tiruchirappalli, has authenticated the Delonix elata. L. I t was ensured that the plant was healthy and uninfected. Collected materials i.e. leaves were collect in bulk quantity. After collection the plant materials are washed properly by using running tap water to remove the adhering soil and dirt particles and then shade dried. Voucher specimen of the plant was deposited at The Rapinet Herbarium, St. Joseph's College, Tiruchirapppalli for further reference. The dried plant materials were coarsely powered and stored in airtight, non-toxic polyethylene bags until used. Leaves were separated and powdered by using blender. It was stored in a freezer for further use.

\section{Preparation of Leaf Extracts}

Fresh leaves (60-80 gm) of $D$. elata were shade dried at room temperature $\left(32-35^{\circ} \mathrm{C}\right)$ to constant weight over a period of 5 days. The dried seeds were ground into powdered using a mortar and pestle. $25 \mathrm{~g}$ of the powdered seeds were separately extracted in $250 \mathrm{ml}$ conical flasks seed powered was packed in soxhlet apparatus. The powdered leaves of $D$. elata was extracted with different solvents like ethanol $\left(60-80^{\circ} \mathrm{C}\right)$ for $24 \mathrm{~h}$ to de-fat it and then the remaining plant materials were extracted by maceration process by using acetone as solvent. Filtered was occurred with the extractives where the solvents were incorporate and subsequently the marc is pressed to squeeze out residual extractives. This process was repeated thrice to achieve complete extraction. The extracts obtained during the three cycles were combined and reduced to $1 / 8$ th of its original volume in a rotary evaporator at $45^{\circ} \mathrm{C}$ and then lyophilized in a freeze dryer to obtain the yield. After obtaining the product the product is concentrated by drying method and then preserved for further study.

\section{Extraction and Isolation of Alkaloids}

Powdered plant material (10 g) was wetted with $15 \mathrm{~mL}$ of $\mathrm{NH}_{4} \mathrm{OH}(25 \%, \mathrm{~m} / \mathrm{m})$ and room temperature solvent extraction was performed with $300 \mathrm{~mL}$ of ethyl acetate for $72 \mathrm{~h}$. The extract was filtered and the solvent was evaporated in a rotary evaporator under reduced pressure at $40{ }^{\circ} \mathrm{C}$. The residue, dissolved in $\mathrm{H} 2 \mathrm{O}$ and acidified with $\mathrm{H}_{2} \mathrm{SO}_{4}$ to $\mathrm{pH} 3-4$, was extracted with petroleum ether and diethyl ether to remove lipophilic, acidic and neutral material. After basifying the aqueous solution to $\mathrm{pH} 9-10$ with $\mathrm{NH} 4 \mathrm{OH}(25 \%, \mathrm{~m} / \mathrm{m})$, it was extracted with chloroform, the extract washed with distilled water to neutral $\mathrm{pH}$, dried with $\mathrm{Na} 2 \mathrm{SO} 4$ and concentrated to dryness under reduced pressure to obtain crude alkaloids.

\section{GC-MS}

The GC-MS analysis for identification of compounds present in different fractions prepared from crude methanol extract of $D$. elata had been carried to identify the compounds. Gas chromatography study includes the important optimization process such as i) introduction of sample extract onto the GC column, ii) separation of its components on an analytical column and iii) detection of target analysis by using mass spectrometry (MS) detector. $5 \mathrm{ml}$ of ethanol extract was evaporated to dryness and reconstituted into $2 \mathrm{ml}$ ethanol. The extracts were then subjected to GC-MS analysis. Chromatographic separation was carried out with instrument GC-MS-QP 2 (SHIMADZU instrument) with $\mathrm{Db} 30.0$ column $(0.25 \mu \mathrm{m}$ diameter $\times 0.25$ $\mu \mathrm{m}$ thickness). The oven temperature was programmed from $70^{\circ} \mathrm{C}$ (isothermal for 5 minutes), with an increase of $10^{\circ} \mathrm{C} / \mathrm{min}$. up to $200^{\circ} \mathrm{C}$, then $5^{\circ} \mathrm{C} / \mathrm{min}$. up to $280^{\circ} \mathrm{C}$ and ending with 35 minutes isothermal at $280^{\circ} \mathrm{C}$. Mass spectra were taken at $70 \mathrm{eV}$; scan interval of 0.5 seconds and scan range from $40-1000 \mathrm{~m} / \mathrm{z}$. Helium was used as the carrier gas at $99.99 \%$ pressure with flow rate of $1.0 \mathrm{ml} / \mathrm{min}$. and electronic pressure control on Samples were dissolved in Acetone and injected automatically. The relative percentage amount of each component was calculated by comparing its average peak area to the total areas. Software adapted to handle mass spectra and chromatograms was a Turbo Mass Version 5.2.0. Interpretation on mass-spectrum.

\section{MS Programme}

Library used NIST Version-Year 2015, Inlet line temperature $200^{\circ} \mathrm{C}$, Source temperature $200^{\circ} \mathrm{C}$ Electron energy:70 eV, Mass scan (m/z): 45-450,Solvent Delay: 0-2 min, Total MS running time:36 min.

\section{Identification of compounds}

Interpretation on mass spectrum generated during GC-MS analysis was done by using National Institute Standard and Technology (NIST) database 2015 to identify the compounds present. To identify the compounds well established known compounds are considered as a standard whereas Unknown compounds of spectra were kept as test in the NIST library by considering different 
parameters like retention time, molecular weight and structure. GC- MS having more 62,000 patterns. The Structure of the compound and the Molecular weight of the compound with name of the test materials were confirmed. The major compounds identified were searched in Dr. Duke's Phytochemical and Ethnobotanical Database.

\section{Source of Microorganisms}

The organisms used were Two gram-positive bacteria such as Bacillus subtilis, Staphylococcus aureus, two gramnegative bacteria Escherchia coli, Pseudomonas aeruginosa, and the two fungal strains Candida albicans and Aspergillus niger. The organisms were obtained from Kauvery Medical Hospital, Tiruchirappalli, Tamil Nadu and maintain according to specification. Sub culturing was done at the interval of 15 days. Bacterial strains were maintained on Nutrient agar slants (Hi media) at $4^{\circ} \mathrm{C}$. The fungal strains were maintained on Sabouraud dextrose agar slants at $4^{\circ} \mathrm{C}$.

\section{Inoculum preparation}

Stock cultures were maintained at $4^{\circ} \mathrm{C}$ on slopes of nutrient agar and sabouraud dextrose agar. Active cultures for experiments were prepared by transferring a loopful of cells from the stock cultures to test tubes of Muller-Hinton broth (MHB) for bacteria that were incubated without agitation for $24 \mathrm{~h}$ at $37^{\circ} \mathrm{C}$ respectively and Sabouraud dextrose broth (SDB) for fungi that were incubated for 72 hours at $27^{\circ} \mathrm{C}$. To $5 \mathrm{ml}$ of $\mathrm{MHB}$ and SDB, $0.2 \mathrm{ml}$ of culture was inoculated and incubated till it reached the turbidity equal to that of the standard $0.5 \mathrm{McF}$ arland solution $8 \mathrm{~h}$ at $600 \mathrm{~nm}$ which is equivalent to $10^{6}-10^{8} \mathrm{CFU} / \mathrm{ml}$. These suspensions were prepared immediately before the test was carried out.

\section{Microbial inoculum preparation}

The nutrient broth and Sabouraud dextrose broth were prepared, then identified bacterial and fungal colonies were inoculated into the broth culture were used for antimicrobial activity.

\section{Determination of Antimicrobial Activity}

The antibacterial and antifungal activity of the D. elata alkaloid leaf extracts was determined using agar well diffusion method by following the known procedure.
Nutrient agar and Sabouraud dextrose agar were inoculated with the given microorganisms by spreading the bacterial and fungal inoculums on the media. Wells of $6 \mathrm{~mm}$ were punched in the agar and filled with plant extracts. Control wells containing neat solvents (negative control) were also run parallel in the same plate. The plates were incubated at $37^{\circ} \mathrm{C}$ for 24 hours and $28^{\circ} \mathrm{C}$ for 72 hours the antimicrobial activity was assessed by measuring the diameter of the zone of inhibition. The antimicrobial activity of the different alkaloid extracts were evaluated by comparing their zones of inhibition with standard antibiotic streptomycin.

\section{RESULTS AND DISCUSSION}

The ethanol leaf extracts of D.elata were tested against the pathogenic bacteria and fungi and viz. B. subtilis which can cause Endocarditis, pneumonia and Septicemia; S. aureus which can cause of skin and soft tissue infections such as abscesses, furuncles and cellulitis; $P$. aeruginosa causes Urinary tract infections, respiratory infections, dermatitis, soft tissue infections, bacteremia bone and joint infections, gastrointestinal infections and variety of systematic infections; E.coli causes cholecystitis, cholangitis, urinary tract infection and traveler's diarrhea; C. albicanse is the most common cause of genital yeast infections and superficial infections; A.niger cause Aspergillosis, allergic reactions, lung infections. Antimicrobial activity of D.elata were seen against four bacteria and two fungus strains. The four different concentration of leaf extracts of D.elata were also used against six microbial pathogens. The ethanol alkaloid leaf extract showed maximum activity against Candida albican and minimum activity against Bacillus subtilis shown in the Table 1 . The alkaloid leaf extracts higher concentration $(100 \mu \mathrm{l})$ showed maximum inhibitory zone $(25 \mathrm{~mm})$ and lower concentration $(25 \mu \mathrm{l})$ showed minimum inhibitory zone $(12 \mathrm{~mm})$ against to $B$. subtilis Table-1.The zone of inhibition of microbial strains was ranged from $12 \mathrm{~mm}$ to $25 \mathrm{~mm}$. The antibacterial and antifungal activity demonstrated by D.elata is suggestive of the presence of compounds and/or possible synergistic interaction of compounds that can disrupt fungal and bacterial membranes. The current finding is an indication of the therapeutic relevance of the tested plants in managing dermatological conditions of bacterial and fungal origin.

Table 1: Antimicrobial activity of D. elata

\begin{tabular}{|c|c|c|c|c|c|c|}
\hline \multirow{2}{*}{ SAMPLE } & \multicolumn{6}{|c|}{ ETHANOL Extract $\mathbf{1 0 0} \boldsymbol{\mu l}$ added and Zone of inhibition (mm/ml) } \\
\hline & $\mathbf{2 5} \boldsymbol{\mu l}$ & $\mathbf{5 0} \boldsymbol{\mu l}$ & $\mathbf{7 5} \boldsymbol{\mu l}$ & $\mathbf{1 0 0} \boldsymbol{\mu l}$ & Control \\
\hline Bacillus subtilis & 12 & 14 & 15 & 16 & 20 \\
\hline Staphylococcus aureus & 14 & 16 & 18 & 22 & 20 \\
\hline Escherchia coli & 15 & 18 & 20 & 23 & 20 \\
\hline Pseudomonas aeruginosa & 12 & 14 & 16 & 18 & 18 \\
\hline Candida albicanse & 16 & 19 & 22 & 25 & 22 \\
\hline Aspergillus niger & 14 & 18 & 20 & 23 & 20 \\
\hline
\end{tabular}


The GC-MS studies revealed that the presence of twentyfive compounds in ethanol alkaloid leaf extract of $D$. elata. The compounds with their Retention Time (RT), Molecular Formula, Molecular Weight (MW) and Peak Area (\%) have been presented in different tables. The major phyto compounds had been identified on basis of the percentage Peak Area in the Chromatograph. The compounds identified in the ethanol alkaloid leaf extract (Table 2 and figure 1) are Styrene, Benzaldenyde, 2,2,4,4,6,6,8,8Octamethyl-1,3,5,7,2,4,6,8-Tetraoxyatertrasilocane, 1Tetradecanol, n-Pentadecanol, Neophytadiene, 3,7,11,15Tetramethyl-2-hexadecen-1-ol, Heptasiloxane, 1,1,3,3,5,5,7,7,9,9,11,11,13,13-Tetradecamethyl -, Dibutyl phthalate, Hexadecanoic acid, ethyl ester, trans,trans9,12-Octadecadienoic acid, propyl ester, Ethyl (9Z,12Z)9,12-Octadecadienoate, Octadecanoic acid, ethyl ester, Cyclooctasiloxane, Hexadecamethyl,1,1,3,3,5,5,7,7,9,9,11,11,13,13,15,15 Hexadecamethyl ocatasiloxane, Cyclonosiloxane, Octadecamethyl-,2,5,7,8Tetramethyl -2-(4,8,12-Trimethyl tridecyl)-3,4-Dihydro2H- Chromen- -YL Hexofuranoside, Cyclodecasiloxane,
eicosamethyl-,Cyclododecasiloxane, Tetracosamethyl,Cyclooctasiloxane, hexadecamethyl-,Z-11,13-

Tetradecadien-1-ol acetate, Cyclononasiloxane, octadecamethyl-, Cyclononasiloxane, octadecamethyl-, Hexacontane, Cyclodecasiloxane and eicosamethyl- may be synergistically responsible for the antimicrobial activity. The GC-MS spectrum confirmed the presence of various components with different retention times as illustrated in [Figure 1, Table 2]. The mass spectrometer analyses the compounds eluted at different times to identify the nature and structure of the compounds. The large compound fragments into small compounds giving rise to appearance of peaks at different $\mathrm{m} / \mathrm{z}$ ratios. These mass spectra are fingerprint of that compound which can be identified from the data library. The present study helps to predict the formula and structure of 25 biomolecules. Further investigation may lead to isolation of bio-active compounds and their structural elucidation and screening of pharmacological activity will be helpful for further drug development ${ }^{8-17}$.

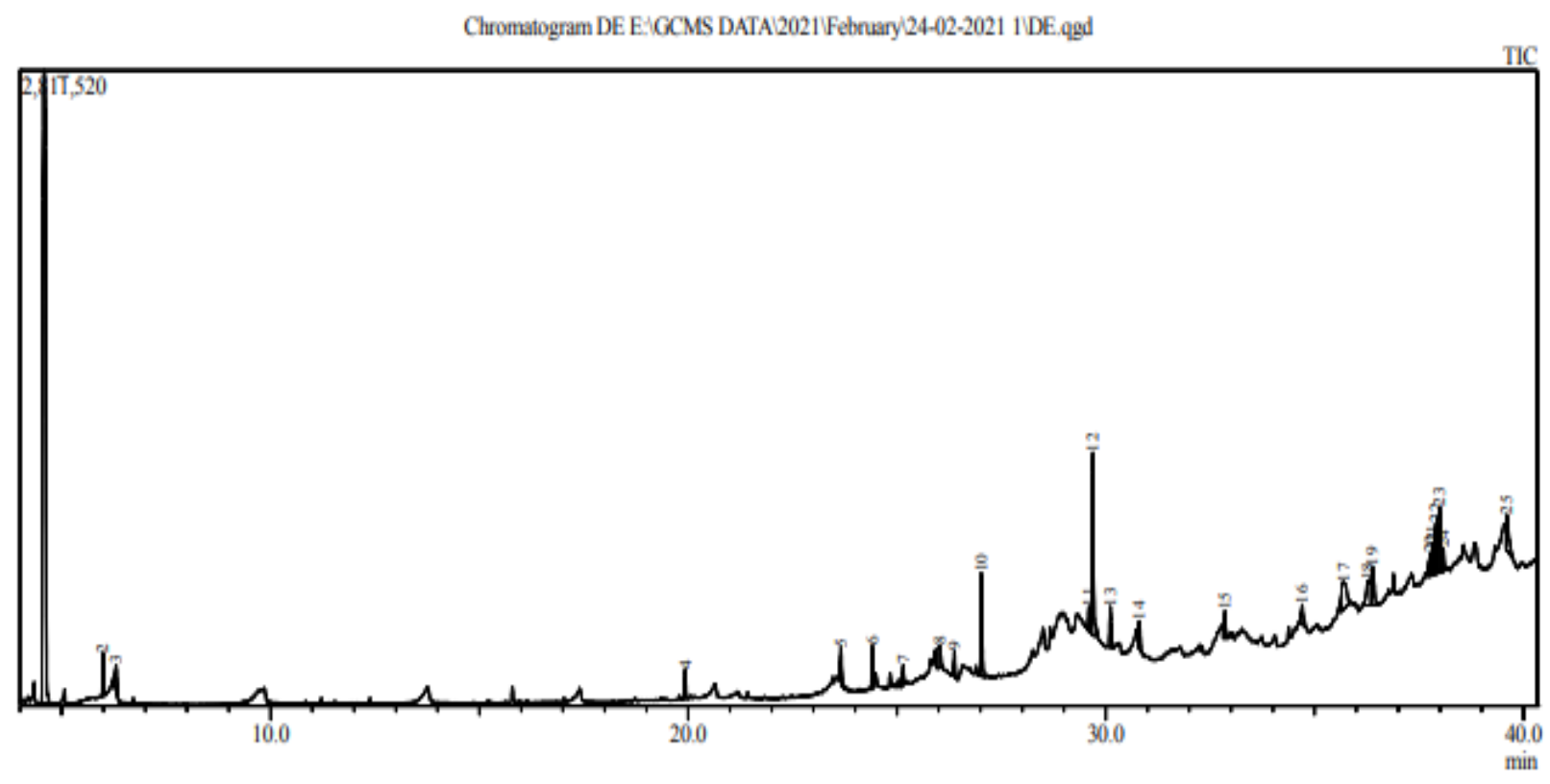

Figure 1: GC - MS analysis of D.elata

Secondary metabolites of plants such as alkaloids, flavonoids, tannins, phenols, saponins, and several other aromatic compounds serve as a defence mechanism against prediction by many microorganisms, insects, and other herbivores. In very small doses, alkaloids had strong biological effects on animal and human organisms. Alkaloids are found not only in food and beverages, but also as stimulant drugs ${ }^{18-26}$. They demonstrated antiinflammatory, anticancer, analgesic, local anaesthetic, and pain relief properties, as well as neuropharmacologic, antimicrobial, antifungal, and other activities. Alkaloids can be used as diet ingredients, supplements, pharmaceuticals, and in medicine, among other things. Alkaloids are also important compounds in organic synthesis for the discovery of new semisynthetic and synthetic compounds that may have greater biological activity than parent compounds ${ }^{27-36}$. Alkaloids are a large class of naturally occurring organic compounds that have a nitrogen atom or atoms (amino or amido in some cases) in their structure. These nitrogen atoms are responsible for the alkalinity of these compounds. These nitrogen atoms are typically found in a ring (cyclic) system. Indole alkaloids, for example, are those that have a nitrogen atom in the indole ring system. Alkaloids are classified into several classes based on their structures, including indoles, quinolines, isoquinolines, pyrrolidines, pyridines, pyrrolizidines, tropanes, terpenoids, and steroids. 
Table 2: GC - MS analysis of Delonix elata.

\begin{tabular}{|c|c|c|c|c|c|c|c|}
\hline S. No & R. Time & $\begin{array}{l}\text { Mass } \\
\text { Peak }\end{array}$ & $\begin{array}{l}\text { Name of the } \\
\text { Compound }\end{array}$ & MW & $\begin{array}{l}\text { Molecular } \\
\text { Formula }\end{array}$ & Molecular Structure & Action \\
\hline 1 & 4.579 & 1 & Styrene & 104 & $\mathrm{C} 8 \mathrm{H} 8$ & & $\begin{array}{l}\text { Antimicrobial } \\
\text { activity }\end{array}$ \\
\hline 2 & 5.994 & 2 & BENZALDEHYDE & 106 & $\mathrm{C} 7 \mathrm{H} 6 \mathrm{O}$ & & $\begin{array}{l}\text { Great anti } \\
\text { Oxidant, } \\
\text { Antimicrobial } \\
\text { Activity }\end{array}$ \\
\hline 3 & 6.305 & 3 & $\begin{array}{c}2,2,4,4,6,6,8,8- \\
\text { OCTAMETHYL-1,3, } \\
\text { 5,7,2,4,6,8- } \\
\text { TETRAOXATETRASILOC } \\
\text { ANE }\end{array}$ & 296 & $\mathrm{C} 8 \mathrm{H} 24 \mathrm{O} 4 \mathrm{Si} 4$ & & $\begin{array}{l}\text { Reactant for } \\
\text { Synthesis of } \\
\text { Ethylhydro } \\
\text { Silicone fluids }\end{array}$ \\
\hline 4 & 19.931 & 4 & 1-Tetradecanol & 214 & $\mathrm{C} 14 \mathrm{H} 300$ & & $\begin{array}{l}\text { Antimicrobial } \\
\text { Activity }\end{array}$ \\
\hline 5 & 23.657 & 5 & n-Pentadecanol & 228 & $\mathrm{C} 15 \mathrm{H} 32 \mathrm{O}$ & & $\begin{array}{l}\text { Lubricating oil, } \\
\text { Consumer } \\
\text { product such as } \\
\text { loations } \\
\text { andcreams }\end{array}$ \\
\hline 6 & 24.412 & 6 & Neophytadiene & 278 & $\mathrm{C} 2 \mathrm{OH} 38$ & & $\begin{array}{l}\text { Antioxident, Anti } \\
\text { inflammatory, } \\
\text { antimicrobial and } \\
\text { algal } \\
\text { metabolite }\end{array}$ \\
\hline 7 & 25.149 & 7 & $\begin{array}{c}\text { 3,7,11,15-Tetramethyl- } \\
\text { 2-hexadecen-1-ol }\end{array}$ & 296 & $\mathrm{C} 2 \mathrm{OH} 400$ & & $\begin{array}{l}\text { Synthesis form } \\
\text { of vitamin E } \\
\text { and vitamin K1 }\end{array}$ \\
\hline 8 & 26.027 & 8 & $\begin{array}{c}\text { HEPTASILOXANE, } \\
1,1,3,3,5,5,7,7,9,9,11,1 \\
1,13,13- \\
\text { TETRADECAMETHYL- }\end{array}$ & 504 & $\begin{array}{c}\mathrm{C} 14 \mathrm{H} 44 \mathrm{O} 6 \mathrm{Si} \\
7\end{array}$ & & $\begin{array}{l}\text { Antimicrobial } \\
\text { Activity }\end{array}$ \\
\hline 9 & 26.375 & 9 & Dibutyl phthalate & 278 & $\mathrm{C} 16 \mathrm{H} 22 \mathrm{O} 4$ & & $\begin{array}{l}\text { Bioactive } \\
\text { Compound, } \\
\text { Antifungal and } \\
\text { Antibacterial } \\
\text { Activity }\end{array}$ \\
\hline 10 & 27.017 & 10 & $\begin{array}{l}\text { Hexadecanoic acid, } \\
\text { ethyl ester }\end{array}$ & 284 & $\mathrm{C} 18 \mathrm{H} 36 \mathrm{O} 2$ & & $\begin{array}{l}\text { Anti oxidant, } \\
\text { Anti } \\
\text { inflammatory, } \\
\text { Antibacterial } \\
\text { activity }\end{array}$ \\
\hline 11 & 29.596 & 11 & $\begin{array}{l}\text { trans,trans-9,12- } \\
\text { Octadecadienoic } \\
\text { acid, propyl ester }\end{array}$ & 322 & $\mathrm{C} 21 \mathrm{H} 38 \mathrm{O} 2$ & & $\begin{array}{l}\text { Biosynthesis of } \\
\text { prostaglandins } \\
\text { acid } \\
\text { Cell membrane }\end{array}$ \\
\hline 12 & 29.688 & 12 & $\begin{array}{c}\text { ETHYL }(9 Z, 12 Z)-9,12- \\
\text { OCTADE } \\
\text { CADIENOATE \# }\end{array}$ & 308 & $\mathrm{C} 2 \mathrm{OH} 36 \mathrm{O} 2$ & & $\begin{array}{l}\text { Anti fungal and } \\
\text { Antibacterial } \\
\text { activity }\end{array}$ \\
\hline
\end{tabular}




\begin{tabular}{|c|c|c|c|c|c|c|c|}
\hline 13 & 30.107 & 13 & $\begin{array}{c}\text { Octadecanoic acid, } \\
\text { ethyl ester }\end{array}$ & 312 & $\mathrm{C} 2 \mathrm{OH} 40 \mathrm{O} 2$ & $\gamma$ & Plant metabolite \\
\hline 14 & 30.799 & 14 & $\begin{array}{c}\text { CYCLOOCTASILOXANE, } \\
\text { HEXADECAMETHYL- }\end{array}$ & 592 & $\begin{array}{c}\mathrm{C} 16 \mathrm{H} 48 \mathrm{O} 8 \mathrm{Si} \\
8\end{array}$ & $400 / 1$ & $\begin{array}{l}\text { Antimicrobial } \\
\text { activity, } \\
\text { Antibacterial } \\
\text { activity }\end{array}$ \\
\hline 15 & 32.85 & 15 & $\begin{array}{c}1,1,3,3,5,5,7,7,9,9,11,1 \\
1,13 \\
, 13,15,15 \text { HEXADECAME } \\
\text { THYLOCTASILOXANE \# }\end{array}$ & 578 & $\begin{array}{c}\mathrm{C} 16 \mathrm{H} 50 \mathrm{O} 7 \mathrm{Si} \\
8\end{array}$ & & $\begin{array}{l}\text { Antimicrobial } \\
\text { activity }\end{array}$ \\
\hline 16 & 34.701 & 16 & $\begin{array}{l}\text { CYCLONONASILOXANE, } \\
\text { OCTADECAMETHYL- }\end{array}$ & 666 & $\begin{array}{c}\mathrm{C} 18 \mathrm{H} 54 \mathrm{O} 9 \mathrm{Si} \\
9\end{array}$ & & $\begin{array}{l}\text { Antibacterial, } \\
\text { Antimicrobial } \\
\text { activity }\end{array}$ \\
\hline 17 & 35.702 & 17 & $\begin{array}{c}\text { 2,5,7,8-TETRAMETHYL- } \\
\text { 2-(4,8,12- } \\
\text { TRIMETHYLTRIDECYL)- } \\
\text { 3,4-DIHYDRO-2H- } \\
\text { CHROMEN-6-YL } \\
\text { HEXOFURANOSIDE }\end{array}$ & 592 & C35H60O7 & & $\begin{array}{l}\text { Antimicrobial, } \\
\text { Antioxidant }\end{array}$ \\
\hline 18 & 36.27 & 18 & $\begin{array}{l}\text { Cyclodecasiloxane, } \\
\text { eicosamethyl- }\end{array}$ & 740 & $\begin{array}{c}\mathrm{C} 20 \mathrm{H} 60010 \mathrm{~S} \\
\mathrm{i} 10\end{array}$ & & $\begin{array}{l}\text { Antiparasitic, } \\
\text { Pesticidal, } \\
\text { antifungal } \\
\text { Activity }\end{array}$ \\
\hline 19 & 36.393 & 19 & $\begin{array}{l}\text { CYCLODODECASILOXA } \\
\text { NE, } \\
\text { TETRACOSAMETHYL- }\end{array}$ & 888 & $\begin{array}{c}\mathrm{C} 24 \mathrm{H} 72 \mathrm{O} 12 \mathrm{~S} \\
\mathrm{i} 12\end{array}$ & & $\begin{array}{c}\text { Antimicrobial, } \\
\text { Antifungal activity }\end{array}$ \\
\hline 20 & 37.77 & 20 & $\begin{array}{l}\text { Cyclooctasiloxane, } \\
\text { hexadecamethyl- }\end{array}$ & 592 & $\begin{array}{c}\mathrm{C} 16 \mathrm{H} 48 \mathrm{O} 8 \mathrm{Si} \\
8\end{array}$ & & $\begin{array}{l}\text { Anticancer, } \\
\text { Antibacterial, } \\
\text { Antimicrobial } \\
\text { activity }\end{array}$ \\
\hline 21 & 37.83 & 21 & $\begin{array}{c}\text { Z-11,13-Tetradecadien- } \\
\text { 1-ol acetate }\end{array}$ & 252 & $\mathrm{C} 16 \mathrm{H} 28 \mathrm{O} 2$ & & $\begin{array}{l}\text { Antioxidant, } \\
\text { Antibacterial } \\
\text { activity }\end{array}$ \\
\hline 22 & 37.9 & 22 & $\begin{array}{l}\text { Cyclononasiloxane, } \\
\text { octadecamethyl- }\end{array}$ & 666 & $\begin{array}{c}\text { C18H54O9Si } \\
9\end{array}$ & & $\begin{array}{c}\text { Antiparasitic, } \\
\text { Pesticidal, } \\
\text { Antimicrobial, } \\
\text { Antifungal activity }\end{array}$ \\
\hline 23 & 37.994 & 23 & $\begin{array}{l}\text { Cyclononasiloxane, } \\
\text { octadecamethyl- }\end{array}$ & 666 & $\begin{array}{c}\mathrm{C} 18 \mathrm{H} 54 \mathrm{OOSi} \\
9\end{array}$ & & $\begin{array}{c}\text { Antiparasitic, } \\
\text { Pesticidal, } \\
\text { Antimicrobial, } \\
\text { Antifungal activity }\end{array}$ \\
\hline 24 & 38.085 & 24 & Hexacontane & 842 & $\mathrm{C} 60 \mathrm{H} 122$ & & $\begin{array}{l}\text { Antibacterial } \\
\text { activity, } \\
\text { Antioxidant } \\
\text { activity }\end{array}$ \\
\hline 25 & 39.602 & 25 & $\begin{array}{l}\text { Cyclodecasiloxane, } \\
\text { eicosamethyl- }\end{array}$ & 740 & $\begin{array}{c}\text { C20H60O10S } \\
\text { i10 }\end{array}$ & & $\begin{array}{l}\text { Antimicrobial, } \\
\text { Antioxidant, } \\
\text { Anticancer } \\
\text { activity } \\
\text { and anti } \\
\text { inflammatory }\end{array}$ \\
\hline
\end{tabular}




\section{CONCLUSION}

Gas Chromatogram Mass Spectrometry (GC-MS) analysis was used to identify twenty three chemical constituents from ethanolic alkaloid leaf extract in this study. The presence of various bioactive compounds justifies traditional practitioners' use of the plant in various ailments. The antimicrobial activities demonstrated by D.elata, despite being at high concentrations, continue to provide a clue to the local traditional system of medicine that employs it. To identify major biologically active phytoconstituents, phytochemical screening was performed. Furthermore, we looked into the biological activity of the powerful alkaloid leaf extracts against a variety of antibacterial and antifungals Agar overlay bioautography assay for strains. It is hoped that these active constituents will provide useful information for the development of new compounds with greater activity against multidrug resistant bacteria and fungi than currently available agents.

\section{REFERENCES}

1. Aguiar JS, Costa MCCD, Nascimento SC, Sena KXFR. Antimicrobial activity of Lippia alba (Mill.) N. E. Brown (Verbenaceae). Rev Bras Pharmacogn. 2008; 18(3): 43640.

2. Alzoreky NS, Nakahara K. Antibacterial activity of extracts from some edible plants commonly consumed in Asia. Int J Food Microbiol. 2003; 80(3): 223-30.

3. Asolini FC, Tedesco AM, Ferraz C, Alencar SM, Carpes ST. Antioxidant and antibacterial activities of phenolic compounds in extracts of plants used as tea. Braz J Food Technol. 2006; 9(6): 209-15.

4. Avancini CAM, Wiest JM, Mundstock EA. Bacteriostatic and bactericidal activity of the Baccharis trimera (Less.) D.C. Compositae decocto, as disinfectant or antisseptic. Arq Bras Med Vet Zootec. 2000; 52(3): 230-4.

5. Barbosa LN, Rall VL, Fernandes AA, Ushimaru PI, da Silva Probst I, Fernandes A Jr. Essential oils against foodborne pathogens and spoilage bacteria in minced meat. Foodborne Pathog Dis. 2009; 6(6): 725-8.

6. Betoni JE, Mantovani RP, Barbosa LN, Di Stasi LC, Fernandes Jr A. Synergism between plant extract and antimicrobial drugs used on Staphylococcus aureus diseases. Mem Inst Oswaldo Cruz. 2006; 101(4): 387-90.

7. Braga FG, Bouzada ML, Fabri RL, Matos MO, Moreira FO, Scio $E$, et al. Antileishmanial and antifungal activity of plants used in traditional medicine in Brazil. J Ethnopharmacol. 2007; 111(2): 396-402.

8. Candan F, Unlu M, Tepe B, Daferera D, Polissiou M, Sokmen $A$, et al. Antioxidant and antimicrobial activity of the essential oil and methanol extracts of Achillea millefolium subsp. millefolium Afan. (Asteraceae). J Ethnopharmacol. 2003;87(2-3):215-20.

9. Costa AC, Santos BHC, Santos Filho L, Lima EO. Antibacterial activity of the essential oil of Origanum vulgare L. (Lamiaceae) against bacterial multiresistant strains isolated from nosocomial patients. Rev Bras Pharmacogn. 2009; 19(1B): 236-41.
10. Costa JGM, Rodrigues FFG, Angélico EC, Pereira CKB, Souza EO, Caldas GFR, et al. Chemical composition and evaluation of the antibacterial activity and toxicity of the essential oil of Croton zehntneri (variety estragol). Rev Bras Pharmacogn. 2008; 18(4): 583-6.

11. Coutinho HDM, Costa JGM, Siqueira-Júnior JP, Lima EO. In vitro anti-staphylococcal activity of Hyptis martiusii Benth against methicillin-resistant Staphylococcus aureus MRSA strains. Rev Bras Pharmacogn. 2008; 18(Supl.): 670-5.

12. Cowan MM. Plant products as antimicrobial agents. Clin Microbiol Rev. 1999; 12(4): 564-82.

13. Duarte MCT, Delarmelina C, Figueira GM, Sartoratto A, Rehder VLG. Effects of essential oils from medicinal plants used in Brazil against EPEC and ETEC Escherichia coli. Rev Bras PI Med. 2006; 8(n.esp.): 139-43.

14. Ferronato R, Marchesan ED, Pezenti E, Bednarski F, Onofre SB. Antimicrobial activity of essential oils produced by Baccharis dracunculifolia D.C. and Baccharis uncinella D.C. (Asteraceae). Rev Bras Pharmacogn. 2007; 17(2): 224-30.

15. Gallucci N, Casero C, Oliva M, Zygadlo J, Demo M. Interaction between terpenes and penicillin on bacterial strains resistant to beta-lactam antibiotics. Mol Med Chem. 2006; 10(1): 30-2.

16. Machado TB, Pinto AV, Pinto MC, Leal ICR, Silva MG, Amaral $A C F$, et al. In vitro activity of Brazilian medicinal plants, naturally occurring naphthoquinones and their analogues, against methicillin-resistant Staphylococcus aureus. Int J Antimicrob Agents. 2003; 21(3): 279-84.

17. Maciel MAM, Pinto AC, Veiga Jr VF, Grynberg NF, Echevarria A. Medicinal plants: the need for multidisciplinary scientific studies. Quim Nova. 2002; 25(3): 429-38.

18. Mbosso EJ, Ngouela S, Nguedia JC, Beng VP, Rohmer M, Tsamo E. In vitro antimicrobial activity of extracts and compounds of some selected medicinal plants from Cameroon. J Ethnopharmacol. 2010; 128(2): 476-81.

19. Menezes MC, Souza MMS, Botelho RP. In vitro evaluation of antimicrobial activity of Brazilian plants extracts on bacteria isolated from oral cavity of dogs. Rev Univ Rural. 2004; 24(2): 141-4.

20. More GK, Tshikalange TE, Lall N, Botha FS, Meyer JJM. Antimicrobial activity of medicinal plants against oral microorganisms. J Ethnopharmacol. 2008; 119(1): 4737.

21. Nascimento GGF, Locatelli J, Freitas PC, Silva GL. Antibacterial activity of plant extracts and phytochemicals on antibiotic-resistant bacteria. Braz J Microbiol. 2000; 31(1): 247-56.

22. Oliveira DG, Prince KA, Higuchi CT, Santos ACB, Lopes LMX, Simões MJS, et al. Antimycobacterial activity of some Brazilian indigenous medicinal drinks. J Basic Appl Pharm Sci. 2007; 28(2): 165-9.

23. Oliveira IS, Lima JCS, Silva RM, Martins DTO. In vitro screening of antibacterial activity of the latex and extracts from Croton urucurana Baillon. Rev Bras Pharmacogn. 2008; 18(4): 587-93. 
24. Oliveira RAG, Lima EO, Vieira WL, Freire KRL, Trajano VN, Lima IO, et al. Study of the interference of essential oils on the activity of some antibiotic used clinically. Rev Bras Pharmacogn. 2006; 16(1): 77-82.

25. Rosato A, Vitali C, Laurentis N, Armenise D, Milillo MA. Antibacterial effect of some essential oils administered alone or in combination with norfloxacin. Phytomedicine. 2007; 14(11): 727-32.

26. Sakagami Y, Kajimura K. Bactericidal activities of disinfectants against vancomycin-resistant enterococci. J Hosp Infec. 2002; 50(2):1 40-4.

27. Salvagnini LE, Oliveira JRS, Santos LE, Moreira RRD, Pietro RCLR. Evaluation of the antibacterial activity of Myrtus communis L. (Myrtaceae) leaves. Rev Bras Pharmacogn. 2008; 18(2): 241-4.

28. Shin S. Anti-Aspergillus activities of plant essential oils and their combination effects with ketoconazole or amphotericin B. Arch Pharm Res. 2003; 26(5): 389-93.

29. Silva Jr. IE, Cechinel Filho V, Zacchino SA, Lima JCS, Martins DTO. Antimicrobial screening of some medicinal plants from Mato Grosso Cerrado. Rev Bras Pharmacogn. 2009; 19(1B): 242-8.

30. Silva MAR, Higino JS, Pereira JV, Siqueira-Júnior JP, Pereira MSV. Antibiotic activity of the extract of Punica granatum Linn. over bovine strains of Staphylococcus aureus. Rev Bras Pharmacogn. 2008; 18(2): 209-12.
31. Silva MSA, Silva MAR, Higino JS, Pereira MSV, Carvalho AAT. In vitro antimicrobial activity and antiadherence of Rosmarinus officinalis Linn. against oral planktonic bacteria. Rev Bras Pharmacogn. 2008; 18(2): 236-40.

32. Silva MTN, Ushimaru PI, Barbosa LN, Cunha MLRS, Fernandes Jr A. Antibacterial activity of plant essential oils against Staphylococcus aureus and Escherichia coli strains isolated from human specimens. Rev Bras PI Med. 2009; 11(3): 257-62.

33. Szalek E, Grzeskowiak E, Kozielczyk J. Interactions between herbal and synthetic drugs. Advantages and risks. Herba Polonica. 2006; 52(4): 153-7.

34. Ushimaru PI, Silva MTN, Di Stasi LC, Barbosa L, Fernandes Jr A. Antibacterial activity of medicinal plant extracts. Braz J Microbiol. 2007; 38(1): 717-9.

35. Ushimaru PI. Estudo in vitro da atividade antibacteriana de extratos de plantas medicinais e sinergismo com drogas antimicrobianas [thesis]. Botucatu: Universidade Estadual Paulista, Instituto de Biociências; 2007. 51 p.

36. Zampini IC, Cuello S, Alberto MR, Ordonez RM, D'Almeida $R$, Solorzano $E$, et al. Antimicrobial activity of selected plant species from "the Argentine Puna" against sensitive and multiresistant bacteria. J Ethnopharmacol. 2009; 124(3): 499-505.

Source of Support: The author(s) received no financial support for the research, authorship, and/or publication of this article.

Conflict of Interest: The author(s) declared no potential conflicts of interest with respect to the research, authorship, and/or publication of this article.

For any question relates to this article, please reach us at: editor@globalresearchonline.net New manuscripts for publication can be submitted at: submit@globalresearchonline.net and submit_ijpsrr@rediffmail.com 